\title{
DESKRIPSI PENDERITA IKTERUS NEONATORUM DI RSUD CUT NYAK DHIEN MEULABOH
}

\author{
Sufyan Anwar \\ Dosen Fakultas Kesehatan Masyarakat Universitas Teuku Umar \\ FKM-UTU, Jalan Alue Peunyareng-Aceh Barat
}

\begin{abstract}
ABSTRAK
Ikterus merupakan kondisi yang paling umum terjadi pada bayi baru lahir dan memerlukan perhatian. Sebagaian besar ditemukan pada minggu pertama kehidupan dan sekitar $10 \%$ bayi yang disusui masih ikterus pada satu bulan. Tujuan dari penelitian ini untuk melihat gambaran jenis kelamin dan berat badan penderita ikterus neonatorum.

Desain penelitian deskriptif dengan menggunakan data rekam medik. Hasilnya ditemukan dari 30 penderita ikterus sebagian besar berjenis kelamin laki-laki (\%) dan sebagian besar berat badan normal (80\%). Disarankan agar Ibu memperhatikan bayinya terutama bayi laki-laki, bayi dengan berat lahir $\geq 3000$ gr. Penelitian dengan desain yang lebih baik diperlukan.
\end{abstract}

Kata Kunci : ikterus, neonatorum, jenis kelamin, berat badan

\section{Pendahuluan}

Masa neonatal (0-28 hari setelah lahir) merupakan masa yang sangat rentan terhadap kejadian yang tidak diharapkan. Pada saat ini seorang anak punya risiko tinggi untuk terjadinya suatu penyakit bahkan kematian. Apalagi kematian neonatal memberi kontribusi sebesar 56\% terhadap kematian bayi (Kemenkes R.I., 2014). Oleh karena itu, perlu adanya perhatian serius terhadap seorang anak pada masa ini, baik oleh keluarga, terlebih lagi petugas kesehatan.

Lima puluh persen (50\%) kematian neonatus secara global diperkirakan terjadi pada 24 jam pertama dan $75 \%$ kematian neonatus terjadi pada minggu pertama kelahiran. Menurut proporsi angka kematian neonatus menurun 1,8\% setiap tahunnya. Walaupun terjadi penurunan, namun masih terjadi 3 juta kematian neonatus setiap tahun. Angka ini adalah $43 \%$ dari seluruh kematian yang terjadi pada semua golongan umur. Berdasarkan urutan negara-negara dengan jumlah kematian neonatus tertinggi di dunia tahun 2010, Indonesia berada pada urutan ke 8 setelah Etopia dan Bangladesh pada urutan ke 6 dan 7 (USAID, Kemenkes, 2013).

Dari Hasil Survey Demografi dan Kesehatan Indonesia (SDKI) menyebutkan angka kematian neonatal pada tahun 2012 ada 19 per 1000 kelahiran hidup. Angka ini turun 
dari 20 per 1000 kelahiran hidup pada tahun 2007 dan 23 per 1000 kelahiran hidup pada tahun 2002 (Kemenkes R.I., 2014). Dapat dilihat bahwa penurunan jumlah kematian neonatus yang terjadi setiap tahunnya tidak menunjukkan hasil yang signifikan. Jika tidak ada upaya keras dari semua pihak, maka Indonesia akan sulit mencapai target MDGs.

Diantara sekian banyak penyebab tingginya AKB atau neonatus, salah satunya hiperbilirubin dengan ciri khas manifestasinya adalah ikterus atau lebih dikenal dengan ikterus neonatorum. Ikterus merupakan kondisi yang paling umum terjadi pada bayi baru lahir dan memerlukan perhatian medis (National Institut for Health and Care Exellence/NICE, 2010). Ia adalah hasil dari peningkatan kerusakan sel darah merah dan atau penurunan ekskresi hepatik bilirubin dengan tanda-tanda klinis termasuk perubahan warna kuning pada kulit dan sclera (Scafford dkk, 2013). Ikterus yang terjadi pada neonatus dapat berbentuk fisiologis maupun patologis. Terjadinya gangguan otak dan kematian pada neonatus merupakan akibat dari ikterus patologik yang tidak ditangani dengan baik (Hidayat, 2009).

Menurut Behrman (1999), secara epidemiologi ikterus terjadi pada $60 \%$ bayi yang lahir cukup bulan dan $80 \%$ pada bayi kurang bulan dan sebagaian besar ditemukan pada minggu pertama kehidupan dan (NICE, 2010) sekitar 10\% bayi yang disusui masih ikterus pada satu bulan. Health Technology Assessment Unit Medical Development Division Ministry of Health Malaysia (2002) dalam Kemenkes R.I. (2013 ) menyebutkan bahwa sebanyak $65 \%$ bayi baru lahir di Amerika Serikat menderita ikterus dalam minggu pertama kehidupannya. Di Malaysia, hasil survei pada tahun 1998 di rumah sakit pemerintah dan pusat kesehatan di bawah Departemen Kesehatan mendapatkan $75 \%$ bayi baru lahir menderita ikterus dalam minggu pertama kehidupannya. Sementara di Indonesia kejadian ikterus neonatorum pada bayi cukup bulan bervariasi dari 13,7\% hingga $85 \%$ dan data ini merupakan data dari beberapa rumah sakit pendidikan, yaitu RSCM, RS Dr. Sardjito, RS Dr. Soetomo, RS Dr. Kariadi (Kemenkes R.I., 2013).

Data tahun 2011 ruang Neonatal Intensive Care Unit (NICU) Rumah Sakit Umum Daerah (RSUD) Cut Nyak Dhien Meulaboh merawat sebanyak sebanyak 14 neonatus dengan kasus ikterus. Pada tahun 2012 jumlah kasus ikterus sebanyak 16 neonatus yang dirawat. Berdasarkan buku register tahun 2012, kasus ikterus menempati urutan kedua terbanyak setelah kasus asfeksia. Dari berbagai jastifikasi yang sudah dijabarkan, 
penulis ingin melihat deskripsi karakteristik penderita ikterus neonatorum di RSUD Cut Nyak Dhien Meulaboh tahun 2011 sampai 2012. Penelitian ini bertujuan untuk mendapatkan informasi tentang penderita ikterus neonatorum menurut jenis kelamin, berat badan dan tempat tinggal.

\section{Metode}

Penulis menggunakan desain penelitian deskriptif dengan pendekatan analisis dokumen untuk mendapatkan informasi yang berguna tentang gambaran penderita ikterus neonatorum. Informasi diperoleh khusus penderita ikterus neonatorum yang dirawat di ruang Neonatal Intensive Care Unit (NICU) RSUD Cut Nyak Dhien Meulaboh dari tahun 2011 s.d. 2012. Jumlah keseluruhan penderita tahun 2011-2012 sebanyak 30 orang.

Variabel penelitian yang diukur merujuk kepada teori Epidemiologi yang dikemukakan Budiarto (2002). Ia menyebutkan bahwa gambaran epidemiologi suatu penyakit dapat dilihat melalui aspek orang, tempat dan waktu. Penentuan ketiga aspek tersebut disesuaikan dengan kebutuhan, kemampuan dan sarana yang ada. Penulis hanya melihat dari aspek orang saja, yaitu menilai jenis kelamin dan berat badan sebagai variabel bebas dan ikterus sebagai variabel terikat. Jenis kelamin didefisikan sebagai suatu sifat (keadaan) pada seseorang yang dengan keadaan tersebut dapat dibedakan jantan (laki-laki) dan betina (perempuan). Berat badan diartikan sebagai

Pengukuran variabel atau pengumpuan melalui pedoman pengisian terhadap variabel penelitian. Pedoman pengisian dijadikan sebagai alat pengumpul data, karena data penelitian menggunakan data sekunder, yaitu data dari dokumen rekam medik dan buku register ruang NICU tentang penderita ikterus. Sementara analisa data yang dilakukan hanya sebatas analisa univariat, yaitu menjelaskan masing-masing variabel penelitian menurut nilai proporsi dan frekuensi. Data disajikan dalam bentuk tabel frekuensi sehingga dapat diketahui proporsi katagori dari masing-masing variabel. Perhitungan nilai proporsi menggunakan rumus sebagai berikut :

$$
\begin{gathered}
{ }^{n}- \\
\mathrm{P}=---\mathrm{X} 100
\end{gathered}
$$


Keterangan :

$\mathrm{P}=$ nilai proporsi

$\mathrm{n}=$ jumlah sampel dalam katagori tertentu

$\mathrm{N}=$ jumlah seluruh sampel

\section{Hasil dan Pembahasan}

Hasil

Penelitian ini hanya melihat gambaran karakteristik penderita ikterus neonatorum (jenis kelamin dan berat badan), sesuai dengan data yang tersedia pada dokumen rekam medis dan buku register. Penulis tidak melakukan analisa keterkaitan atau hubungan sebab akibat. Sehingga informasi yang didapatkan menjadi sangat terbatas. Dari 30 penderita ikterus neonatorum yang diteliti, sebagian besar laki-laki (67\%) dan 80\% memiliki berat badan normal.

Tabel 1 Distribusi Frekuensi Penderita Ikterus Neonatorum

\begin{tabular}{lcc}
\hline \multicolumn{1}{c}{ Jenis Kelamin } & Frekuensi & Persentase \\
\hline Laki-laki & 20 & $67 \%$ \\
Perempuan & 10 & $33 \%$ \\
\hline Jumlah & 30 & $100 \%$ \\
\hline
\end{tabular}

Tabel 2 Distribusi Frekuensi Penderita Ikterus Neonatorum Menurut Berat Badan

\begin{tabular}{lcc}
\hline \multicolumn{1}{c}{ Berat Badan } & Frekuensi & Persentase \\
\hline Normal & 24 & $80 \%$ \\
Rendah & 6 & $20 \%$ \\
\hline Jumlah & 30 & $100 \%$ \\
\hline
\end{tabular}




\section{Pembahasan}

\section{Jenis Kelamin}

Setiap penyakit dapat menyerang setiap orang baik laki-laki maupun perempuan, namun pada beberapa penyakit terdapat perbedaan frekuensi antara laki-laki dan perempuan. Hal ini antara lain disebabkan perbedaan pekerjaan, kebiasaan hidup, genetic atau kondisi fisiologis dan lain-lain. Secara konsep epidemiologi, penyakitpenyakit tertentu lebih dominan ditemukan menurut jenis kelamin, baik laki-laki ataupun perempuan. Hal ini kemungkinan karena tingkat kepekaan dari jenis kelamin tertentu terhadap penyakit tersebut. Penelitian yang penulis lakukan menunjukkan kejadian ikterus neonatorum yang dirawat di RSUD Cut Nyak Dhien Meulaboh lebih banyak laki-laki dari pada perempuan. Hasil ini diperkuat oleh penelitian yang dilakukan Scrafford dkk (2013) di Nepal Selatan. Mereka menemukan adanya hubungan jenis kelamin dengan kejadian ikterus neonatorum (P-value $<0,001$ ). Jenis kelamin laki-laki lebih berisiko terjadinya ikterus neonatorum dibandingkan dengan perempuan. Setelah dilakukan penyesuaian analisis multivariat, jenis kelamin tetap menjadi faktor penting yang berkaitan dengan ikterus neonatorum.

\section{Berat Badan}

Penggunaan pendekatan epidemiologi deskriptif dari sisi orang, selain jenis kelamin juga dapat dilihat dengan menilai berat badan seseoorang. Berat badan biasanya dihubungkan dengan kondisi nutrisi atau status gizi. Semakin baik status gizi seseorang, maka kemungkinan orang tersebut lebih sehat dibandingkan dengan orang dengan staus gizi kurang baik (Budiarto, 2002).

Penulis tidak mendapatkan informasi yang akurat tentang data berat badan penderita pada saat lahir. Data berat badan yang didapatkan adalah berat badan berdasarkan hasil penimbangan pada saat penderita masuk ke rumah sakit. Hasilnya memperlihatkan bahwa bayi yang dirawat di RSUD Cut Nyak Dhien Meulaboh dengan kasus ikterus neonatorum didominasi penderita dengan berat badan normal. Scrafford dkk (2013) menemukan ada keterkaitan berat badan dengan kejadian ikterus neonatorum (P-value $<0,01)$. Berat badan lahir tinggi $(\geq 3000$ gr) memiliki risiko lebih tinggi terhadap terjadinya ikterus dibandingkan dengan berat lahir $<3000$ gr. Berat lahir tetap menjadi faktor penting terhadap kejadian ikterus neonatorum setelah dilakukan penyesuaian melalui analis is multivariat. 
Apabila dikaitkan dengan data berat badan yang penulis temukan yang berupa data bukan berat lahir, melainkan hasil timbangan saat penderita tiba di rumah sakit. Ada kemungkinan dari sisi waktu, sejak atau selama dirumah dan belum dirujuk ke rumah sakit, berat lahir para penderita $\geq 3000$ gr. Sehingga seiring perjalanan waktu dan kondisi penderita yang semakin tidak membaik, berat badan penderita yang saat lahir tinggi menjadi normal sebagaimana data penelitian yang didapat. Jika benar demik ian, maka hasil penelitian ini sangat sesuai dengan studi Scrafford dkk.

Selain berat badan, konsumsi air susu ibu (asi) juga menjadi faktor risiko terjadinya ikterus. Pada ibu-ibu yang kurang atau tidak keluar asi pada minggu-minggu pertama setelah melahirkan, mengakibatkan bayinya kekurangan cairan. Keadaan ini memungkinkan bayinya terjadi ikterus neonatorum (Dennet, 2001 dalam Kemenkes, 2004).

\section{Keterbatasan Penelitian}

Keterbatasan dari penelitian ini adalah sebagai berikut :

1. Penelitian ini bersifat deskriptif, sehingga tidak bisa diketahui variabel-variabel yang mempengaruhi terjadinya ikterus.

2. Data yang digunakan hanya data sekunder, sehingga terbatas pada data yang tersedia di rumah sakit saja.

\section{Kesimpulan dan Saran}

\section{Kesimpulan}

Berdasarkan data rekam medis RSUD Cut Nyak Dhien Meulaboh dari tahun 20112012, terdapat 30 penderita ikterus neonatorum yang sebagian besar adalah laki-laki dan sebagian besar penderita mempunyai berat badan normal pada saat ditimbang di rumah sakit.

\section{Saran}

Ibu-ibu yang baru melahirkan agar betul-betul memperhatikan perawatan bayinya terutama bayi laki-laki, bayi dengan berat lahir $\geq 3000$ gr dan memperhatikan perubahan-perubahan pada bayi, seperti warna kulit dan mata. Pemberian pengetahuan tentang perawatan bayi, pengetahuan tentang ikterus neonatorum oleh petugas kesehatan yang terlibat, mulai masa ante natal sampai masa awal post natal. Penelitian 
lebih lanjut diperlukan dengan desain yang lebih baik dan melalui uji statistik (kuantitatif) atau kualitatif terhadap faktor risiko terjadinya ikterus neonatorum.

\section{Daftar Pustaka}

Behrman, Richard E, Robert M, Ann M. Arvin, 1999. “Ilmu Kesehatan Anak Nelson”, Ed. 15, EGC, Jakarta

Budiarto, Eko \& Dewi Anggraini, 2002. "Pengantar Epidemiologi", Ed. 2, EGC, Jakarta

Hidayat, A Aziz Alimul, 2009, “Pengantar Ilmu Kesehatan Anak Untuk Pendidikan Kebidanan”, Salemba Medika, Jakarta.

Indonesia. Kemenkes R.I. 2014. "Profil Kesehatan Indonesia Tahun 2013”, [Online], Dari: http://www.kemkes.go.id, [17 Februari 2015] , 2013. "Ringkasan Eksekutif Data dan Informasi Kesehatan Provinsi Aceh" Pusat Data dan Informasi Kemenkes RI.

, 2004 "Tatalaksana Ikterus Neonatorum", [Online], Dari: www.depkes.go.id, [18 Oktober 2013]

Junadi, Purnawan et. all. 1982 "Kapita Selekta Kedokteran". Ed. 2. Media Asculapius, Jakarta

Murti, Bhisma. 2010, "Desain dan Ukuran Sampel untuk Penelitian Kuantitatif dan Kualitatif di Bidang Kesehatan”, UGM Press, Yogyakarta

National Institute for Health and Care Exellence. 2010, "Neonatal Jaundice" NICE acreditet, [Online], Dari: http://www.nice.org.uk [07 Juni 2015]

Scrafford, Carolin G dkk. 2013, "Incidence of and risk factors for neonatal jaundice among newborns in southern Nepal" Tropical Medecine and International Health, [Online], vol. 18, no. II, pp. 1317-1328. Dari: http://www.onlinelibrary.wiley.com [07 Juni 2015]

Singarimbun, Masri \& Sofian Effendi. 1989, "Metode Penelitian Survey”, Ed. Rev, LP3ES, Jakarta

Subana, H,M, Sudrajat. 2005 “Dasar-Dasar Penelitian Ilmiah”, Pustaka Setia, Bandung Trisnantoro, Laksono, 2013 "Seminar Kontroversi SDKI 2012 dan Strategi Penurunan Kematian Ibu Bayi” [Online], Dari: www.kebijakankesehatanindonesia.net [21 Desember 2013] 